\title{
Homecomings: Black Women's Mobility in Early African American Fiction
}

\section{Anna Pochmara}

\section{(2) OpenEdition \\ Journals}

Electronic version

URL: https://journals.openedition.org/ejas/16001

DOI: 10.4000/ejas.16001

ISSN: 1991-9336

Publisher

European Association for American Studies

\section{Electronic reference}

Anna Pochmara, "Homecomings: Black Women's Mobility in Early African American Fiction", European journal of American studies [Online], 15-2 | 2020, Online since 30 June 2020, connection on 08 July 2021. URL: http://journals.openedition.org/ejas/16001 ; DOl: https://doi.org/10.4000/ejas.16001

This text was automatically generated on 8 July 2021.

Creative Commons License 


\title{
Homecomings: Black Women's Mobility in Early African American Fiction
}

\author{
Anna Pochmara
}

And now with the speed of an arrow-having passed the avenue-with the distance between her and her pursuers constantly increasing, this poor hunted female gained the "Long Bridge," as it is called, where interruption seemed improbable, and already did her heart begin to beat high with the hope of success. (Brown, Clotel 184)

With the speed of a bird, having passed the avenue, she began to gain, and presently she was upon the Long Bridge. Panting, gasping, she hushed her babe, appealed to God in broken sentences, and gathered all her courage to dash across the bridge and lose herself in the friendly shelter of the woods. (Hopkins, Hagar's Daughter 74)

I do not think that that slave mother who took her four children, crossed the ohio River on the ice, killed one of the children and attempted the lives of the other two, was a contented slave. And that other one, who, running away and finding herself pursued, threw herself over the Long Bridge into the Potomac, was evidently not satisfied. (Harper, Iola Leroy 98)

1 The epigraphs from three different mulatta novels ${ }^{1}$ all rewrite the same story of a slave mother jumping with a child into the Potomac. The jump scene, whose affective force was exploited both in abolitionist discourse and in postbellum literature, aptly introduces this article's focal point and illustrates its significance. I will show how representations of black women's bondage and mobility in early African American fiction complexly recast and problematize the hegemonic ideologies of domesticity and separate spheres as well as counter-hegemonic depictions of mobile and heroic black masculinity in slave narratives. ${ }^{2}$ The corpus will consist of three mulatta melodrama novels: William Wells Brown's Clotel (1853), Frances Ellen Watkins Harper's Iola Leroy (1893), and Pauline Elizabeth Hopkins's Hagar's Daughter (1901-1902). All three texts feature mulatta protagonists and tell strikingly parallel stories, engaging in interesting dialogical relations. They are driven by the melodramatic peripeteia that Brown summarizes in the title of one of Clotel's chapters as "To-day a Mistress, Tomorrow a 
Slave." After a sudden and unexpected withdrawal of white male protection, mulatta wives and daughters are remanded to chattel slavery, which produces a chiaroscuro effect in which the binaries such as freedom/slavery, humanity/commodity are both reversed and challenged.

\section{Introduction: Sentimentality, Abolitionism, and the Woman Question}

2 A focus on mobility will enable me to add to the growing body of scholarship that has reclaimed the critically long-shunned mulatta protagonist. In the selected novels, she is a strategic choice, which makes the extensive travel of the African American characters more plausible. My reading of the black women's enslavement, forced movement, and self-determined mobility will be positioned in the context of two discursive and literary fields. First of all, the novels resonate with nineteenth-century hegemonic women's culture, its diverse reform activism as well as the literary tradition conceptualized by Nina Baym as "woman's fiction" and Jane Tompkins as the "sentimental novel." Secondly, the theme of mobility as represented in the texts-especially their recasting of bondage and escape-echoes abolitionist rhetoric and the genre of the slave narrative. Those two discursive fields are related in many ways; however, from the perspective of this article, the most relevant of these overlapping spaces is their concern with captivity and confinement.

3 In the intersections of abolitionism and nineteenth-century women's movements, the figures of the woman and the slave have been both historically and rhetorically related. Until the end of the Civil War, abolitionists and suffragists closely cooperated (Davis 30-45), ${ }^{3}$ and the rhetorics of the two causes compared the woman's condition to slavery and posited African Americans as the feminine race (Sánchez-Eppler, "Bodily Bonds" 33; Dorsey 186-194). As far as the theme of mobility is concerned, its limitations were a means of subordination of African Americans as well as women, and hence both reform movements addressed this issue. As the narrator in Iola Leroy states, "the slaves were denied unrestricted travel" (4), and analogously the nineteenth-century "social structures [were] designed to keep women in their place" in both metaphorical and literal way (Steadman 4). Antislavery reform institutions, such as the Underground Railroad, helped slaves escape to the North or to Canada, and women's reform movements also contested, though in more subtle ways, middle-class women's sense of confinement and isolation in the private sphere. One of such challenges to the separate spheres ideology was the very act of activism, which aimed to extend the woman's influence into the public space (Epstein 132-137). Accordingly, in literary tradition, canonical slave narratives were driven by the desire to escape from slavery, and in a similar way, woman's fiction, as Baym claims, also challenged the separate spheres ideology, extending the realm of the private sphere "so that home values dominated the world" (48). Hence, despite the dramatic difference between the literal bondage of slaves and largely symbolic confinement of women ${ }^{4}$ in American cultural imagination, the two groups were associated with immobility, which was challenged in abolitionist discourse as well as in woman's fiction and reform rhetoric.

4 The intersection of travel restrictions for African Americans and women is vividly showcased in the renowned Crafts escape. In 1848, Ellen Craft cross-dressed as a man and passed as white to make the couple's travel more plausible, which powerfully 
highlights the privileged position of white male mobility in nineteenth-century cultural codes, ideologies, and practices. The Crafts' escape thrilled the audiences of abolitionist lectures (Zackodnik 49) and was fictionalized by Brown in Clotel and Hopkins in Hagar's Daughter. Due to their simultaneous focus on black emancipation and women's concerns, the mulatta novels I discuss in this article highlight and simultaneously complicate the overlapping spaces of abolitionist discourse and contemporary hegemonic women's culture analogously to the Crafts' story.

Despite their excessive melodramatic aesthetics, explicitly or implicitly, all three novels are related to the slave narrative tradition and its discourse of authenticity. It is most conspicuous in the case of Clotel, which was authenticated by Brown's slave narrative published in the same volume. At the end of the text, he also lists many sources that the novel draws on, including "narratives ... from the lips of those who, like [himself], have run away from the land of bondage" and "American Abolitionist journals" (208). His declaration has been confirmed by literary historians. For example, the central episode of the novel, cited in the epigraph-Clotel's jump into the Potomac -is based on Congressman Seth M. Gates's account "Slavery in the District: The Escape" published in the New-York Evangelist in 1842 (Johnson 14). Writing in the postbellum era, Harper recasts Brown's authenticating gesture and ends with a note stating that Iola Leroy is a story woven "from threads of fact and fiction" (282) and, as critics have pointed out, it heavily references the historiography of black emancipation (Foreman 90-102). Moreover, as the third epigraph illustrates, the text also contains references to historical events popularized by the abolitionist movement, including the death in the Potomac recorded by Gates. Hagar's Daughter, in turn, quotes a number of passages from Clotel, almost word for word, including the Gates/Brown Potomac jump story and thususing the strategy that Augusta Rohrbach calls "literary 'sampling"' (484)-it also participates in the process of historical legitimization. Additionally, as I will argue, Hagar's Daughter draws on a postbellum discourse that appropriated the conventions of the antebellum slave narrative: the novel echoes the Progressive Era white slavery hysteria and "white slave narrative literature": memoirs of prostitutes published by the social purity reformers, which drew on conventions of the black slave narrative.

6 The tradition of the canonical slave narrative, dominated by male voices, is rooted in the philosophy of individualism and autonomy and is based on the paradigm that begins with the state of bondage in the South and ends with unrestrained freedom in the North. As Valerie Smith points out, masculinity was central for the genre, as the narrative traditionally represented "a journey from slavery to freedom but also a journey from slavery to manhood” (34). Brown's, Harper's, and Hopkins's narratives discussed here transcend this binary paradigm, which primarily stems from their focus on families rather than individuals and on women rather than men. This breach between the tradition of the male slave narrative and the mulatta novel is bridged by the canonical narrative written by Harriet Jacobs. Incident's in the Life of a Slave Girl in many ways undercuts its own authenticity and incorporates the sentimental tradition (Patton 54), and in contrast to the male individualist narratives, it dramatizes the relatedness of family members under slavery. Yet, despite its similarities to the novels I analyze, it principally follows the linear South-North itinerary, and as Jacobs alias Linda Brent famously states, her story "ends with freedom, not with marriage" (224).

7 The relevance of hegemonic woman's fiction for the African American mulatta tradition has been acknowledged by a number of critics (Tate 65-66; McDowell 29; 
duCille 4, 17; Raimon 8). There are so many different intersections between the two bodies of writing, however, that the potential of intertextual readings of white women's novelistic tradition and mulatta novels has not been exhausted. One of the yet unexamined parallels is the melodramatic reversal that opens the narratives of both traditions. In her classic study of nineteenth-century novels authored by women, Baym claims that the deep structure of woman's fiction is the story of an allegedly orphaned girl, frequently a pauperized heiress, who is exploited by her guardians and bravely stands the trials of poverty and homelessness, gains independence, and triumphs (3539)..$^{5}$ The story of a young girl in financial trouble resulting from her father's failure to protect the family neatly parallels the narrative reversal of "to-day a mistress, tomorrow a slave" characteristic for mulatta melodrama (Brown 120). Additionally, all three mulatta narratives feature young women separated from their families and mistreated by their protectors, which echoes the paradigm of "neglected and overworked orphans" and guardians who abuse their authority, two central archetypes of woman's fiction (Baym 37). By depicting and celebrating female independence and agency, the novels discussed in Baym's Woman's Fiction challenged the subordination and women's confinement to their homes. More specifically, they did not perceive the home and the world "as separate spheres" but voiced a message that "woman's sphere is to reform the world" (Baym 48-49). The mulatta novel depicts female mobility and emphasizes women's agency in an even more extensive way. Since they incorporate the escape plot from the slave narrative, the texts repeatedly depict protagonists traveling in public spaces and cannot be characterized as "largely descriptive of events taking place in a home setting" (Baym 26). Even more significantly, the novels represent enslavement, bondage, and forced travel, which highlights the dramatic difference between white women's relegation to the private sphere and status of black female slaves as private property.

8 All three mulatta novels begin with a depiction of idyllic domestic scenery, yet analogously to woman's fiction, they principally challenge the separation of home and world. Their openings are positioned in a setting whose privacy and seclusion are emphasized, and thus they express the sense of isolation, which is parallel to the experience of white middle-class women's confinement in the domestic sphere as analyzed by Barbara Epstein and Nancy Cott (77-84; 63-100). The black authors represent life in a home completely divided from the world as a brief, dangerous, and tragic fantasy. In the novels, in the antebellum context, the women's initial isolation in and confinement to the private sphere soon change into literal bondage, and their shelters are exposed as prisons. Clotel and her daughter Mary, Hagar and her daughter Jewel, Marie and her daughter Iola, all begin as mistresses of their respective cottages, mansions, and plantations, and are soon enslaved or re-enslaved as a result of the white father's/slave owner's irresponsibility, ambitions, or death. As far as the narrative structure is concerned, the idyllic openings are characterized by slow-paced, extensive passages of description, which are contrasted with a rapid diegetic tempo, which is classified as a summary in Gérard Genette's typology of narrative movements (94-106).

The women's bondage is represented not only as confinement and immobility but primarily as an enforced movement. It exemplifies what Susan Roberson discusses as forced travel, which paradoxically indicates powerlessness rather than autonomy typically associated with mobility and is closely related to loss rather than quest (98). ${ }^{6}$ The forced movement into slavery is in most cases resisted by the protagonists' attempts at escape. Yet in contrast to the dominant slave narrative paradigm, the 
movements of female characters in fiction are complex and circular, and thus they depart from the traditional linear movement of the fugitive slave from the South to the North, from slavery to freedom. Beginning with a family disintegration and striving towards a family reunion, the novels simultaneously follow two or three generations of family members. Such a construction of the narrative frequently results in chaos and fragmentation, thus depicting the unpredictability and instability of the fate of black families under slavery. Yet in these complex narratives, almost all female characters make a circular trajectory that takes them back closely or exactly to the point of their departure rather than to the North as in the case of the tradition of the male slave narrative. Apart from the geographically circular character of their journeys, these are also symbolic homecomings; the mulattas return to their birthplaces, to their hometowns, or even, as one critic claims, to their African origins (Johnson 11-26).

In order to rigorously examine the circular movements of characters and visualize their homecomings, I will use maps that depict the separation of the mixed-race families and the female protagonists' movements. I will juxtapose these figures with a reading of the narrative means that are employed to represent the characters' travels. In order to produce precise graphic visualizations of mobility, I will chronologically analyze the texts, and each section will be devoted to a separate novel, beginning with Brown's Clotel and ending with Hopkins's Hagar's Daughter.

\section{Clotel: "Death is Freedom" or "Vessels bound for Europe"}

11 Jewel-in contrast to Brown's and Harper's younger generation protagonists-is quite unexpectedly denied a happy ending after her mixed-race identity is discovered because she has been engaged to Cuthbert Sumner, a white Northerner who does not approve of interracial marriages. As she admits in a letter to her fiancé, "Like Miriam of old, I have scorned the Ethiopian and the curse has fallen upon me" (282). Hopkins refers here to the sister of Moses, who-in one of the dominant interpretations of this bible passage-criticizes Moses's "Cushite" wife. Used synonymously with Ethiopian, the adjective was widely regarded as a reference to the wife's racial origin as "Cushite," which derives from "Kush," a kingdom in ancient Nubia, today's Sudan ("Kush"). In the biblical story, God curses Miriam with leprosy. Hopkins's use of the biblical passage foreshadows the very ending, narrated from Cuthbert's perspective, which states that "a righteous God" and his "wrath" will punish the "nation's [sin]-the "idolatry of the Moloch of Slavery" (283-284). Cuthbert, having found out that Jewel has a drop of black blood, hesitates about his further actions. In the meantime, she leaves with her parents for Europe, dies of Roman fever, and is buried at Enson Hall in a conspicuously pastoral setting. The cause of death and daisies near her grave clearly allude to James's famous 1878 novella. Yet, in contrast to James's Daisy, whose grave is a "raw protuberance among the April daisies" "in the little Protestant cemetery, by an angle of the wall of imperial Rome" (82), Jewel is brought back to the US and buried in a "little graveyard nestled close beside the road, . . . [the] enclosure [where] dead and gone Ensons slumbered for centuries" (283). Hence ultimately both Hagar and Jewel return to their point of departure, one to live happily with her original husband in an interracial union, the other to be buried among her predominantly white ancestors (fig. 7). This unexpected ending-especially when juxtaposed with the numerous implausible events 
of the novel's melodramatic plot-highlights the unlikelihood of willful interracial marriages at the turn of the twentieth century. Also-in contrast to Brown's and Harper's texts, where the daughter's story is more hopeful than the mother'sHopkins's vision of American history-typically for the melodramatic mode, represented as a history of families and generations-is not that of progress but of, at least temporary, decline.

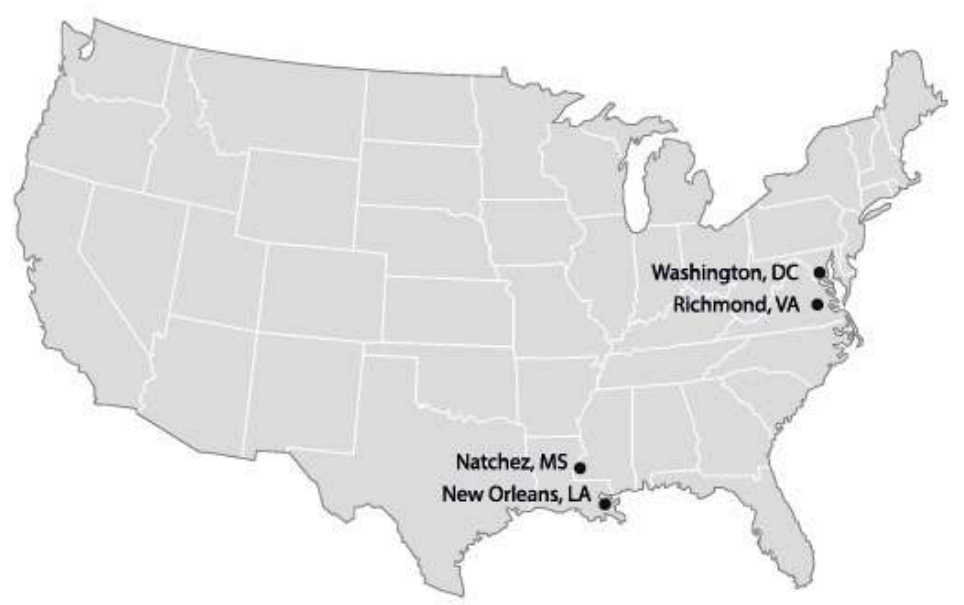

Figure 1. Family separation in Clotel and Clotelle

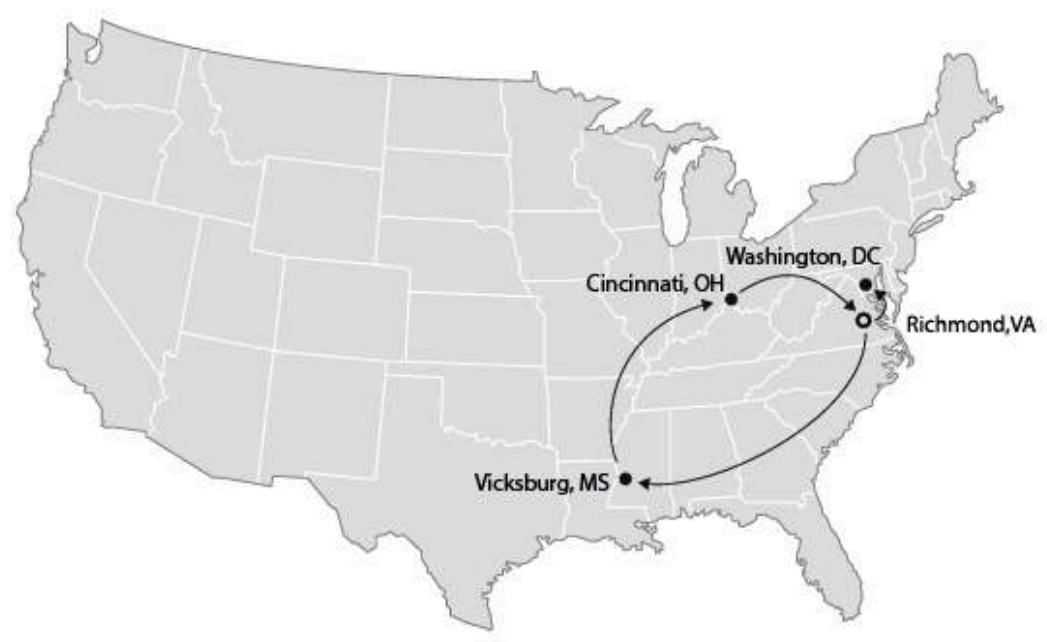

Figure 2. Clotel's journey in Clotel. 

newspaper account of Gates, exploits the democratic irony of the setting (Heermance 85). Clotel dies "within plain sight of the President's house and the capitol of the Union" (Brown 184). He also makes sure that the reader remembers the particular significance of Washington, DC, for Clotel, reminding that she was the "daughter of Thomas Jefferson, a president of the United States; the author of the Declaration of American Independence" (184). The clearly political meaning of Clotel's death in the public sphere forms a dramatic contrast with "long-drawn-out death scenes, in which a saintly woman dies a natural death at home" that, according to Tompkins, characterize the sentimental novel (38). Not only does the scene turn a woman's death into a political action, but-as Brown mentions the home of the President and Jefferson's fatherhood-it also melodramatically highlights the private elements of the public and exposes what Karen Sánchez-Eppler refers to as "a crack in the hegemonic rhetoric of political disembodiment" (Touching 1). Jefferson-president and author-perfectly symbolizes nineteenth-century national body that grants citizenship only to "incorporeal" white men (Touching 3), yet this official position as a founding father is undercut here with his function as a biological father, whose necessarily bodily character is additionally dramatized by the reader's knowledge of the illicit character of his extra-marital thus intensely sexualized relationship with Currer. There is also another possibility to read the jump scene, which focuses on the direction of the Potomac rather than on the white house. From this perspective, Clotel turns to her matrilineal roots. As Lynn R. Johnson argues, her jump can serve as a connection to "her African forebears in the Black Atlantic world," who jumped into the ocean during the Middle Passage (13). Psychoanalytically, death in water can also be seen as a regressive return to the womb. In such a reading, the Potomac becomes a way back to the maternal arche of Africa, which even further underlines the circular trajectory of Clotel. Thus, Brown's protagonist's itinerary can be read as a return along both patrilineal and matrilineal lines.

Clotel's daughter Mary, equally resistant to her condition of bondage, signifies on her mother's flight and thus indirectly also on Ellen Craft's successful escape. As Teresa Zackodnik puts it, "in a clever parody of the child following the condition of the mother, Brown has Mary pose as the rebel slave George so that he can escape prison. Like her mother before her, Mary conceives of a plan to enable the freedom of a male slave by dressing as a man" (57). Her scheme helps her beloved George to escape, yet it leads her to an auction block. Saved from slavery in a dramatic narrative twist by Mr. Devenant, an unexpectedly introduced Frenchman, she moves to France. As a result, in the first, 1853 version of the novel, constructed by Brown for the British audience, Mary is the only character discussed here whose journey does not form a circular trajectory. As Fabi argues, "[c]ompounding a brilliant stoke of abolitionist propaganda with a critique of American democratic ideals that flattered British liberals, Brown presents exile as Mary's only option to secure freedom and safeguard her chastity" (14). Her fate is thus is at least partially determined by the antebellum context. Furthermore, in contrast to Clotel, Mary replicates male slave trajectories. Neither a wife nor a mother when she leaves the US, she is free to follow a more individualist, linear route.

14 However, in the postbellum, 1867 version of the novel, retitled Clotelle; or, The Colored Heroine: A Tale Of The Southern States, although Brown dramatically tempers his critical 
edge (Fabi 23-28), he also adjusts the ending to the post-Emancipation context. This revision enables the homecoming of Mary's character, now renamed Clotelle, from France. ${ }^{7}$ Before that happens, however, Mary/Clotelle makes a more complex journey than the 1853 Mary, whose travels were depicted very briefly. Clotelle travels to France from New Orleans via Natchez, where she is enslaved at Poplar farm, the very place where her grandmother Currer was enslaved. Later, in France, she is miraculously reunited with her first lover (called Jerome in the 1867 version) in Dunkirk just like her 1853 equivalent, yet-rather than settle them down and provide the novel with the closure of marriage-the text depicts their travels in an extensive way:

Everything being arranged for a wedding tour extending up the Rhine, the party set out the same day for Antwerp. There are many rivers of greater length and width than the Rhine. Our Mississippi would swallow up half a dozen Rhines. The Hudson is grander, the Tiber, the Po, and the Mincio more classic; the Thames and Seine bear upon their waters greater amounts of wealth and commerce; the Nile and the Euphrates have a greater antiquity; but for a combination of interesting historical incidents and natural scenery, the Rhine surpasses them all. (98)

15 In the span of this short passage, Brown lists and compares as many as ten rivers from Europe, Africa, the Middle East, and the United States, thus signaling his own and by extension his community's wide knowledge and experience of the world. Significantly, he names the Nile and the Euphrates as the most ancient, thus pointing to the African and Middle-Eastern origins of Western culture. ${ }^{8}$ Brown makes the couple travel along the Rhine through Coblenz, Brussels, and Cologne, and stop for a sojourn in Geneva:

\footnotetext{
After strolling over miles and miles of classic ground, and visiting castles, whose legends and traditions have given them an enduring fame, our delighted travellers started for Geneva, bidding the picturesque banks of the Rhine a regretful farewell. Being much interested in literature, and aware that Geneva was noted for having been the city of refuge to the victims of religious and political persecution, Jerome arranged to stay here for some days. (99; emphasis added)
}

Here Brown again exploits the political associations of geographical names and forms an analogy between persecuted Reformation advocates and fugitive slaves.

The reunited couple then goes to "the little town of Ferney, on the borders of Lake Leman" (99), which becomes the setting of another coincidental meeting: Mary/Clotelle encounters her white father, who in the version released for the American audience is not President of the United States but an ordinary white plantation owner. After the family reunion, however, they neither return to Richmond nor settle down. Instead, the reader is informed that "[m]any were the excursions [Mary/Clotelle] made under the shadows of Mont Blanc, and with her husband and father for companions; she was now in the enjoyment of pleasures hitherto unknown" (103). Subsequently, Brown takes the reunited family back to Geneva and yet again highlights the emancipatory symbolism of the city:

For more than three weeks, this little party spent their time in visiting the birthplace of Rousseau, and the former abodes of Byron, Gibbon, Voltaire, De Stael, Shelley, and other literary characters.... We can scarcely contemplate a visit to a more historic and interesting place than Geneva and its vicinity. Here, Calvin, that great luminary in the Church, lived and ruled for years; here, Voltaire, the mighty genius, who laid the foundation of the French Revolution, and who boasted, "When I shake my wig, I powder the whole republic," governed in the higher walks of life. (103-104) romantic poets as well as figures representing the Reformation movement, the 
Enlightenment, and the French Revolution, Brown legitimizes the resistance of his black slave characters and writes it into the mainstream of modern Western history. Hence, the extensive space devoted to the travels of freed American slaves do not serve any clear narrative function, they do not move the action forward, but predominantly function as signifiers of freedom and unrestrained mobility, further underlined by the connotative significance of the above-mentioned places, that is the ideals of modernity such as revolution, reformation, and progress.

In the 1867 version of his novel, Brown adds four chapters on the Civil War to make it relevant in the contemporary political situation. Mary/Clotelle and George/Jerome return to New Orleans so as to join the union ranks (105). George/Jerome enlists into the army and is fatally wounded, whereas Mary/Clotelle travels from Louisiana to Andersonville, GA, where she helps black prisoners escape (107). Ultimately, she succeeds, and "[l] ong suspected of too freely aiding Union prisoners," Mary/Clotelle is "charged with a knowledge of the escape of these men, and...compelled to leave Andersonville" (111). After being finally imprisoned for her Union sympathies in New Orleans, and in turn, aided in her escape by a black woman, in the novel's closure, she returns to Natchez, where she and her grandmother were separately enslaved:

In the summer of 1866, the Poplar Farm, on which she had once lived as a slave, was confiscated and sold by Government authority, and was purchased by [Mary/ Clotelle], upon which she established a Freedmen's School, and where at this writing,-now June, 1867,-resides the "Angel of Mercy." (114)

Foreshadowing Iola Leroy's trajectory, the 1867 Mary/Clotelle uses her white father's money to buy the very plantation where she was kept as a slave, thus completing her complexly circular trajectory (fig. 3), which was available neither to her mother nor to the 1853 version of her character. In contrast to the following mulatta melodramas, Brown's last version of the novel still retains the pre-Emancipation rhetoric, and it cannot imagine a full black family reunion that constitutes the climactic moment of Harper's and Hopkins's novels. Paradoxically, it also makes Mary/Clotelle the most unlimited and individualist of mulatta melodrama protagonists, foreshadowing the Harlem Renaissance novels of Nella Larsen or Zora Neale Hurston.

\section{Iola Leroy: "Delightful Reunions"}

21 In Iola Leroy, just as in Clotel, the termination of male authority resulting from the death of the white father leads to a disintegration of the interracial family and prompts Iola's forced mobility. The reader is introduced to the eponymous heroine only in the fifth chapter of the novel, when having been "sold from State to State," "seben times in six weeks" (42; original spelling), she is enslaved and incarcerated in the city of C--- (most likely Charlotte), North Carolina. Simultaneously, as the reader learns later, her mother Marie is in Vicksburg and her brother Harry in Maine (fig. 4). Unlike Clotel and Mary, Iola does not resort to cross-dressing and is not the one to initiate escape. Harper decides on a more plausible solution, and Iola is rescued by black fugitives on their way to join the Union army, who-much less plausibly-include her uncle Robert, a close family member she has never met. Like "a trembling dove," she is taken from "the gory vulture's nest and given a place of security" (39). Yet, despite these initial images of vulnerable submission, Harper's Iola does not perpetuate the stereotype of the tragic and passive mulatta. After she is saved by the Northern army, she joins "a new army 
that had come with an invasion of ideas" (146; emphasis added). Iola becomes a teacher, and tutoring is metaphorically represented as a political action. Apart from the military tropes, teaching is positioned as resistance since "one of the powers of knowledge is the power of the strong to oppress the weak" (147).

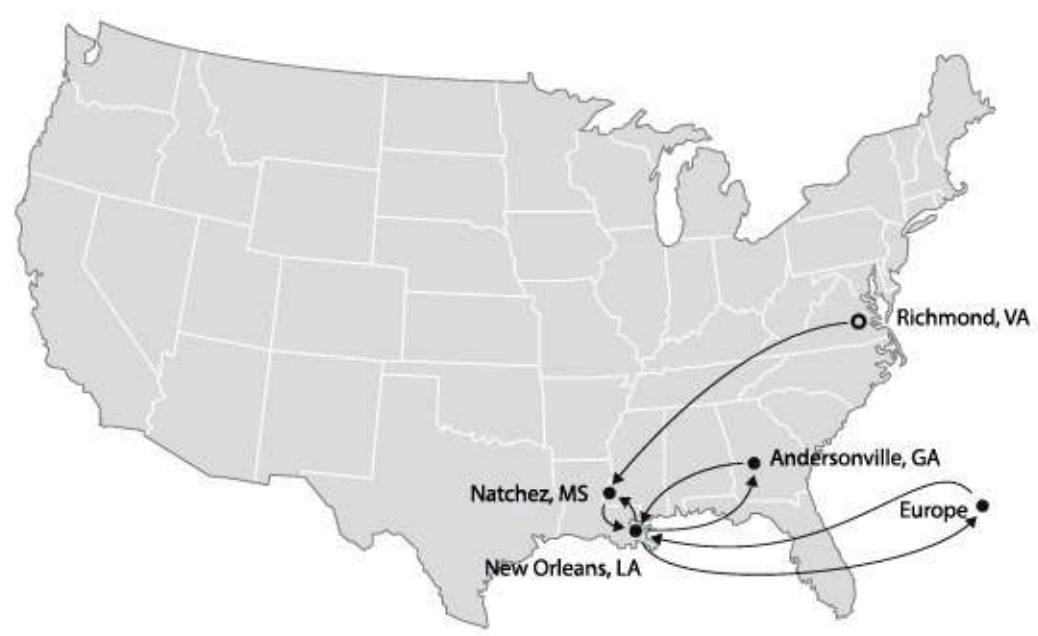

Figure 3. Clotelle's journey in Clotelle

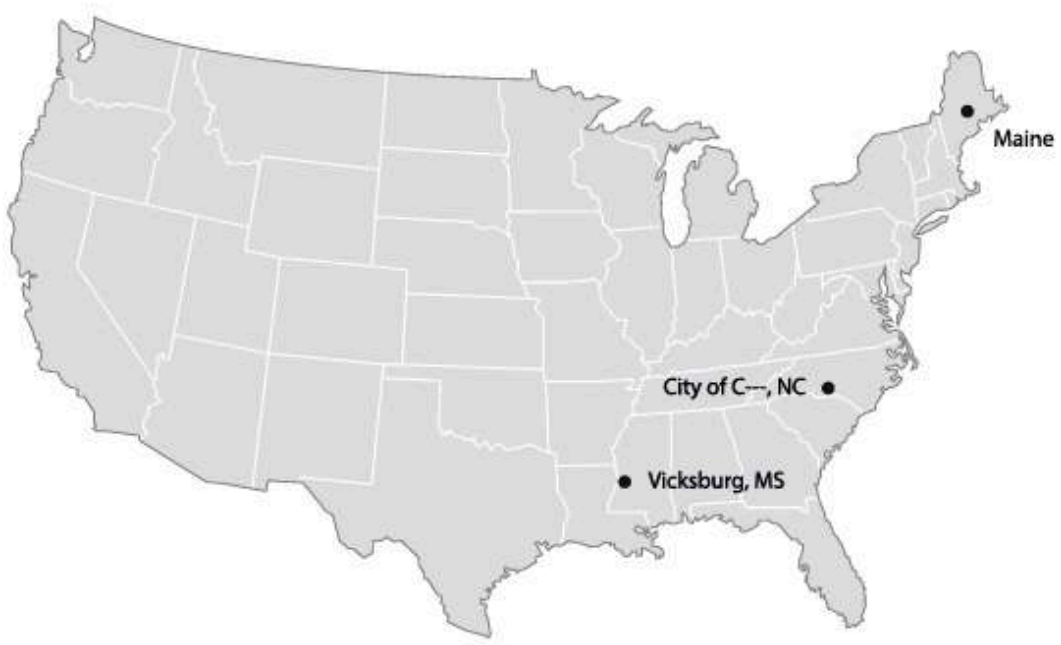

Figure 4. Family separation in Iola Leroy

Iola, just like Clotel, tries to find her family members. She declares that she will "search for [her] mother until [she] find[s] her" (142), and, again mimicking Clotel, after her liberation, she goes down South to Georgia instead of going North. During her extended search for family, Iola's forced travels as a bondwoman are counterbalanced with selfdetermined traveling, which includes a trip by train on her own as well as carriage rides. When depicting an excursion into the countryside, Harper highlights Iola's 
enjoyment of such idyllic "delightful" experiences (175). As a result of her travels, she soon reunites with her grandmother (chapter XX, "A Revelation"), as well as her mother Marie and brother Harry (chapter XXII, "A Further Lifting of the Veil"). Harper resorts to a number of coincidences and excessive evidence that includes lockets, beauty spots, moles, and children's songs to make those family reunions possible. The fact that such narrative excess is necessary for the happy ending highlights the unlikelihood of family reunions.

Even though the search for her mother is Iola's repeatedly declared mission, and the desire to reintegrate the black family drives the narrative of the novel, the text does not end with the series of chapters titled "A Revelation," "A Home For Mother," "Further Lifting Of The Veil," and "Delightful Reunions," which in detail depict the recognitions and reconnections of Marie's mother Harriet and her brother Robert; Marie, Harry, and Iola; as well as Marie, Robert, and Harriet. After all these reunions, instead of the expected ending, the reader follows the protagonist for another nine chapters set in the North until the final chapter takes Iola back to the South. Her extended travels, which do not move the plot forward, echo Mary/Clotelle's excursions to European landmarks, yet their symbolic significance is quite different. Before the ultimate reunion and marriage take place, Iola first moves to the city of P--- (probably Philadelphia) and later to H--- (probably Hartford) in New England, where she is refused a place in a boarding house on account of her race. She comes back to P---, where after much difficulty, she finds different jobs and takes part in the intellectual life of the African American community. With these seemingly redundant chapters that do not contribute to any conflict resolution, the text represents the economic displacement of black people after Emancipation and highlights their determined search for employment with the endless migrancy it entails.

In the final chapter, having gotten engaged to a black doctor, Iola comes back down South to become the mistress of her own house and a Sunday school teacher in the very town where she was imprisoned at the beginning of the novel. Thus Harper signifies on the 1867 plotline of Mary/Clotelle, who opens a school for freedmen on the very plantation where she was a slave. The city of C--- in North Carolina frames the novel, and the narrative comes full circle (fig. 5). In the twisted plots of the text, the city turns out to be the hometown of Iola's grandmother Harriet and the birthplace of her mother Marie, which further emphasizes the centrality of homecoming and circularity for the narrative. Once the complex family reunion is complete, three generations of women live in the same city in North Carolina. Harper's Iola Leroy, written at an optimistic historical moment, "upon the threshold of a new era" (282), differs from Brown's novel rooted in the antebellum times as well as from Hopkins's text, published after the Plessy $v$. Ferguson decision legitimized Jim Crow segregation nationwide, lynching violence deeply marred interracial relations and the failure of Reconstruction was generally acknowledged. Thus, Iola Leroy is the only of the melodramas I analyze here to close with a univocal happy ending for all mulatta characters. 


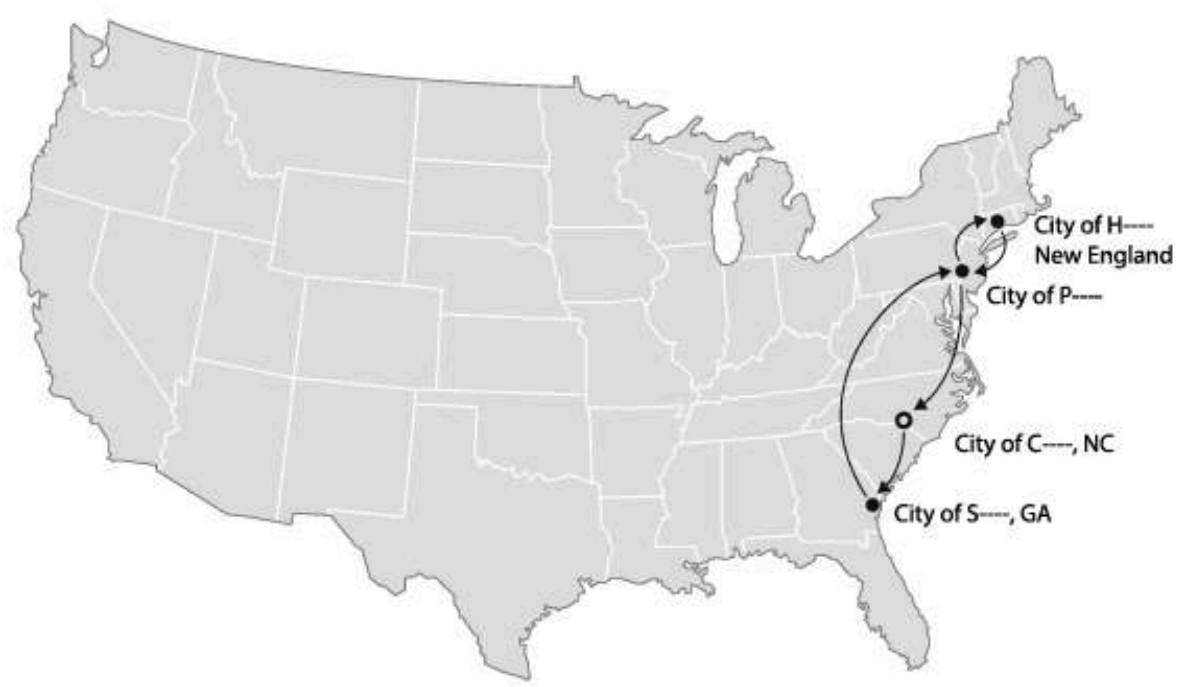

Figure 5. Iola's journey in Iola Leroy

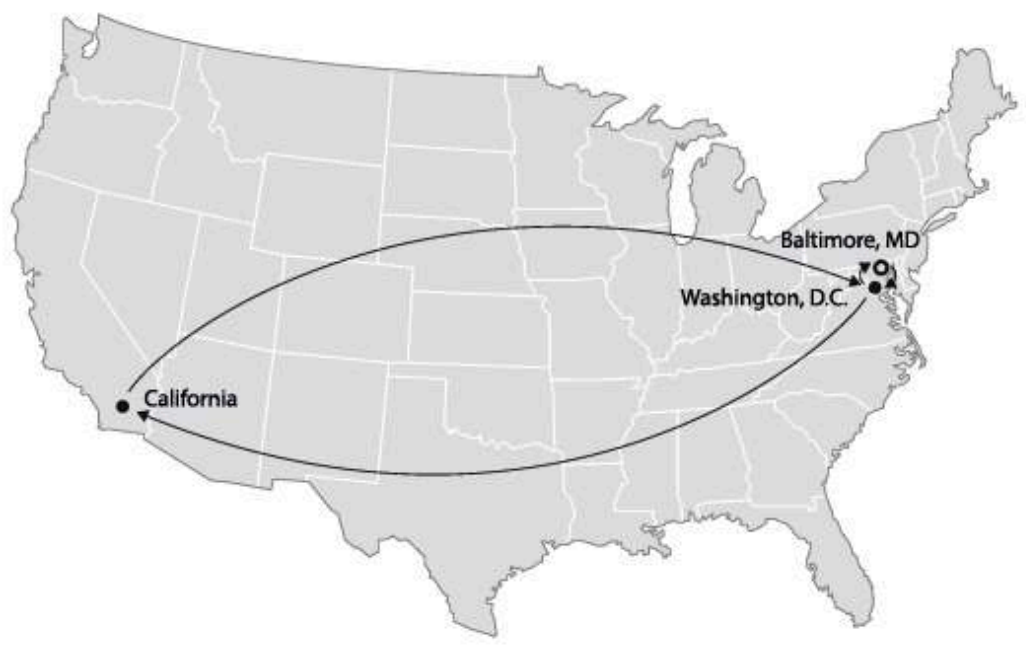

Figure 6. Hagar's journey in Hagar's Daughter

\section{Hagar's Daughter: Slavery and Traffic in Women}

As I have mentioned, Hagar's Daughter even more directly than Iola Leroy signifies on Clotel's narrative. The mulatta plot begins and ends in a similar region-suburban Baltimore-and in an analogously idyllic setting. Hagar, the only daughter of the elite Sargeant family, gets married to her neighbor Ellis Enson from a family of equal social standing. Characteristically, the courtship and marriage of the mixed-race woman are narrated in a single chapter, and in the next episode, published in the same 
installment, due to a plot devised by the evil brother of her husband St. Clair Ensonshe finds out that she is, in fact, a black slave, adopted by the Sargeant family. In the next installment-after her husband's protection is terminated by his alleged suicideshe is transferred to a slave trader. The pace closely resembles the action-packed sequences from the beginning of Brown's novel and also can be classified as Genette's notion of summary. As the epigraph illustrates, Hagar, just like Clotel, flees from the slave pen in Washington to the woods of Arlington. Hopkins literarily quotes from Brown's narrative, retaining many of his original sentences and phrases in her description, and exchanging a number of minor lexical items for their synonyms: "woodlands" for "forest," "mass" for "throng," "side" for "shore," "cross" for "pass" (73-74). Perhaps the most telling of these substitutions is that of "a flying arrow" for "a bird," since it foreshadows the resurrection the narrative has in store for Hagar (74). Apart from constructing this intratextual rebirth, Hopkins, by rewriting Brown (and indirectly also Gates), intertextually resurrects the character of Clotel and reunites her with her daughter. In contrast to Clotel-whose body is "picked up from the bank of the river, where it had been washed by the strong current" and "deposited, without either inquest being held over it, or religious service being performed" in "a hole dug in the sand" (186)-Hagar is miraculously saved by an oyster digger, and "drift[s] to California" (266), where she gets married and comes back to Washington, DC, a wife of a Senator Bowen (fig. 6), thus again signifying on the relations between mulattas and white politicians, which were central for Clotel. Hagar's choice of the Western route interestingly resonates with the classical Western's protagonist's frequent Southern background. Just as defeated Confederate soldiers a decade later, she looks at the frontier for the freedom that the South could not offer at the time. Additionally, California and the West, even though only briefly mentioned, are significant for the novel's logic in general. The region serves to explain Bowen's honest, rough, self-made manhood as well as Hagar's daughter's courage and independence. Jewel-introduced as a "Western girl"-always carries a gun with her just like the mythical cowboy (211).

Hagar's Daughter's second part narrates a story that signifies both on the novel's first part and indirectly, on Brown's Clotel. First of all, Jewel coincidentally follows the route of her mother: she is rescued and then adopted by Zenas Bowen, who takes her to the West. Jewel returns to Washington, DC, via Canada, where she gets an education in a convent. In the context of African American travel writing, the Canadian episode can be read as echoing the Underground Railroad and the final destination of many slave narratives. In the second part of the novel, a slightly changed family-the mother and the daughter are the same as in the antebellum section, the father is a different elite white man-is yet again disintegrated by the plotting of the same evil Enson brother. Since it is set in the 1880s, the characters are not sent back to slavery. Instead, Hagar's daughter is kidnapped by St. Clair and imprisoned in the now ruined family mansion.

Such a juxtaposition of slavery and kidnapping may be read as an allusion to the contemporary discourse of white slavery and traffic in women. At least since 1885, when British reformer William Stead exposed the traffic in young girls in his "The Maiden Tribute to Babylon," the metaphor of white slavery captivated the public, and its influence continued through the entire Progressive Era (Hobson 142). As Ruth Rosen argues, at the dawn of the twentieth century, "American reformers soon took up the banner of both the 'new abolitionism' and the fight against the white slavery" from their British counterparts, and many "former abolitionists ... now joined forces with 
'social purity' reformers to battle the new slavery" (117). Thus in many ways, the turnof-the-twentieth-century social purity movement drew on abolitionist discourse and slave narratives. The story of Jewel in Hagar's Daughter closely parallels typical contemporary white slave narratives-"tales of the conspiratorial abduction of pure womanhood into the grips of the prostitution establishment" (Bristow 100). Hopkins thus recasts the white slave narrative paradigm that necessarily echoes the black slave narrative, creating a complex palimpsest of a text. She uses the contemporary dominant anxieties about white women to reinforce her readers' affect for her mulatta protagonists and thus to mobilize their wider response to the nation's greatest sin, that is, the "idolatry of the Moloch of Slavery" (Hopkins 283). ${ }^{9}$

Just as it is in the case of Clotel, Mary, Iola, and Hagar, Jewel's initial forced movement is followed by resistance, an attempt at escape, and self-determined mobility. Also, just as the previous novels, also Hagar's Daughter devotes much more space to her escape than to her seizure. Hagar's daughter, "a Western girl," bravely resists her kidnappers (211). After some time in confinement, she manages to find a secret passage from the summer house where she is imprisoned to the slave quarters. Thus she retraces the probable route of white male inhabitants to black bondwomen: it "had evidently led to the servants' quarters at the back of the house when mirth and gaiety held high revel in the glorious old mansion" (215; emphasis added). The proximity of the words "house" and "mirth" might be seen as the novel's subtle critique of the "good old" glorious days, when read as a reference to the biblical verse that locates "fools" in "the house of mirth" (Ecclesiastes 7.4). Depicting Jewel's discovery of the passage, Hopkins highlights her skills in observation and logical deduction: "a small strip of canvas swung to and fro as if from a draught of air... She trembled with sudden hope... There was a narrow recess behind it. . . . Oh! Joy! It revealed a passage. . . Escape seemed very near" (215). Jewel provides a model for the female mystery book protagonist almost 30 years before the release of the Nancy Drew series. However, the melodramatic narrative toys with the reader's expectations, and the discovery of the secret tunnel does not directly liberate Jewel. At the end of the way, instead of liberty, the heroine finds another prisoner, her and her mother's black mammy, Aunt Henny Sargeant, also kidnapped by the same band of villains. The twist foregrounds relationality among the novel's characters and downplays individualism, autonomy, and linear movement from bondage to freedom.

Ultimately, Jewel is saved by another protoplast of the Nancy Drew figure-her own cross-dressed female servant Venus, who "evolves from being a black maid to becoming the heroine of the story" (Carby, Introduction xxxix). Hopkins puts her at the center of the novel's action: after Jewel's abduction, "the brain of the little brown maid was busy. She had her own ideas about certain things, and was planning for the deliverance of her loved young mistress" (218). Venus uses cross-dressing in the rescue plan, which is yet another way in which Hopkins signifies on the Crafts' story and Brown's rewriting of it with her poetics of "literary 'sampling"' (Rohrbach 484). Additionally, as Venus replays Clotel's escape in male attire and Hagar replays Clotel's jump into the Potomac, the two characters-the black lower-class girl and her mulatta employer-are intertextually united. Moreover, Venus saves not only Jewel but also her own grandmother, Aunt Henny, imprisoned in the same place. This reinforces the interrelatedness of Venus's and Hagar's families, the family of visibly black servants and the interracial family of almost white mulattas, and as a result, it highlights the significance of the former. In the scene that is the novel's equivalent of Iola Leroy's 
chapter "Delightful Reunions," Hagar alias Mrs. Bowen serves festive supper to celebrate the family reunion after Jewel's deliverance. The two mulatta charactersJewel and Hagar-are reunited with their black "mammy" Aunt Henny (Jewel unknowingly at this stage), which is analogous to Iola Leroy's reunions of the three generations of mulattas. In contrast to the traditional use of visibly black and lowerclass characters as comic relief even by African American authors, the novel critically investigates intraracial, interracial, and class divisions. In Mrs. Bowen's parlor, Hopkins invites the class of black servants and masters to dine together at one table, and Hagar's attention is evenly divided "between her step-daughter and the old Negress [Aunt Henny]" (240). In this fragment, the narrative is yet unaware that all characters are African American, the scene thus presents a common celebratory supper of a white and a black family, during which Aunt Henny is "an honored guest," "all thoughts of caste" are forgotten, and "the representatives of two races [meet] on the ground of mutual interest and regard" (240; emphasis added). In the light of the revelations in the novel's finale, Hopkins's use of "race" is wrought with irony. Hagar's Daughter challenges interracial divisions by pointing out that class divisions are by far more dramatic than those between races, yet simultaneously, she elevates her lower-class female characters to the status of heroines, thus at least partially bridging also the socioeconomic gap.

Jewel-in contrast to Brown's and Harper's younger generation protagonists-is quite unexpectedly denied a happy ending after her mixed-race identity is discovered because she has been engaged to Cuthbert Sumner, a white Northerner who does not approve of interracial marriages. As she admits in a letter to her fiancé, "Like Miriam of old, I have scorned the Ethiopian and the curse has fallen upon me" (282). Hopkins refers here to the sister of Moses, who-in one of the dominant interpretations of this bible passage-criticizes Moses's "Cushite" wife. Used synonymously with Ethiopian, the adjective was widely regarded as a reference to the wife's racial origin as "Cushite," which derives from "Kush," a kingdom in ancient Nubia, today's Sudan ("Kush"). In the biblical story, God curses Miriam with leprosy. Hopkins's use of the biblical passage foreshadows the very ending, narrated from Cuthbert's perspective, which states that "a righteous God" and his "wrath" will punish the "nation's [sin]-the "idolatry of the Moloch of Slavery" (283-284). Cuthbert, having found out that Jewel has a drop of black blood, hesitates about his further actions. In the meantime, she leaves with her parents for Europe, dies of Roman fever, and is buried at Enson Hall in a conspicuously pastoral setting. The cause of death and daisies near her grave clearly allude to James's famous 1878 novella. Yet, in contrast to James's Daisy, whose grave is a "raw protuberance among the April daisies" "in the little Protestant cemetery, by an angle of the wall of imperial Rome" (82), Jewel is brought back to the US and buried in a "little graveyard nestled close beside the road, ... . [the] enclosure [where] dead and gone Ensons slumbered for centuries" (283). Hence ultimately both Hagar and Jewel return to their point of departure, one to live happily with her original husband in an interracial union, the other to be buried among her predominantly white ancestors (fig. 7). This unexpected ending-especially when juxtaposed with the numerous implausible events of the novel's melodramatic plot-highlights the unlikelihood of willful interracial marriages at the turn of the twentieth century. Also-in contrast to Brown's and Harper's texts, where the daughter's story is more hopeful than the mother'sHopkins's vision of American history-typically for the melodramatic mode, 
represented as a history of families and generations-is not that of progress but of, at least temporary, decline.

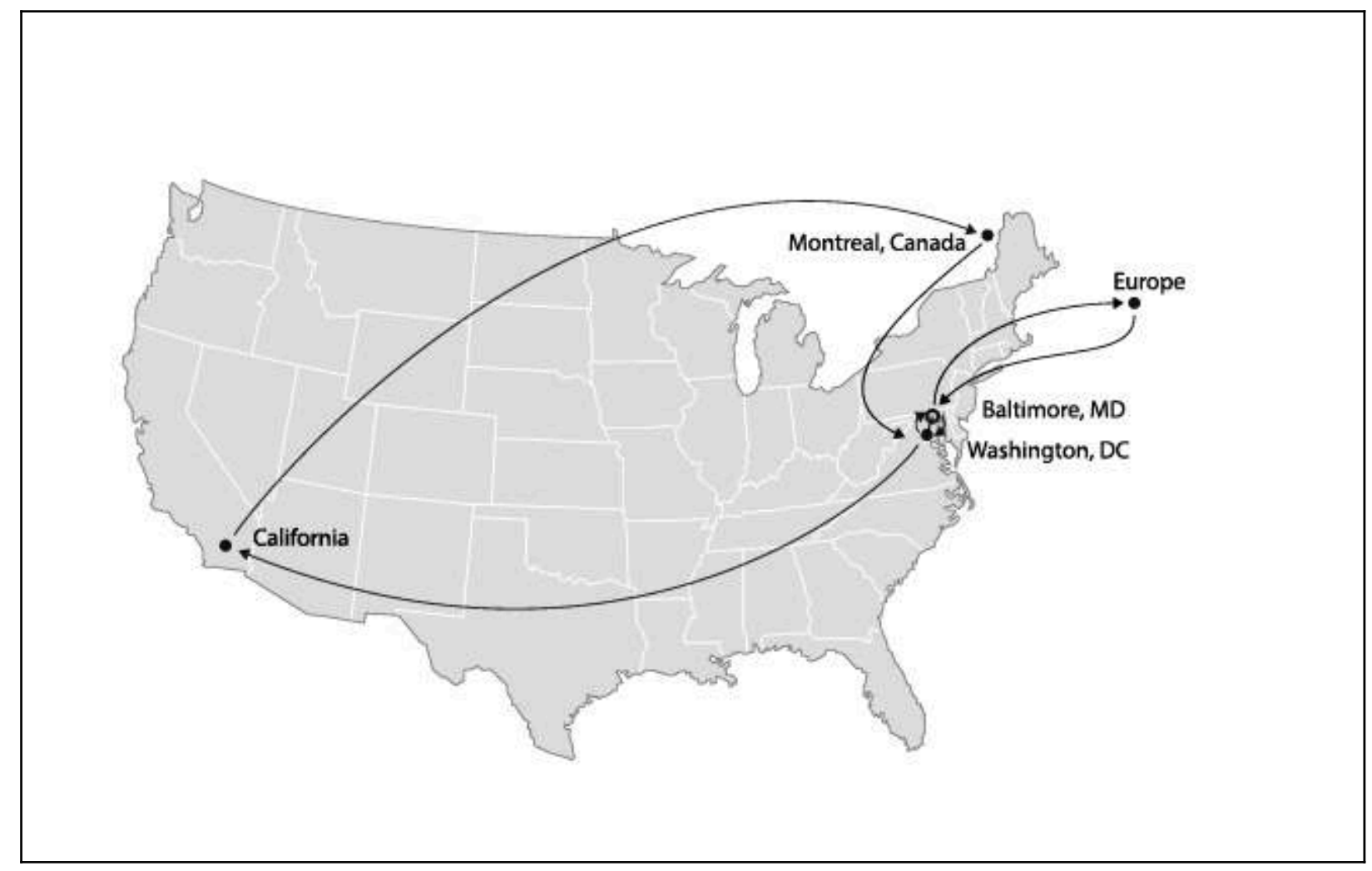

Figure 7. Jewel's journey in Hagar's Daughter

On the other hand, if the reader focuses on the lower-class black heroines rather than on the mulattas, Hopkins's narrative is as almost optimistic as Harper's. Not only are the three generations of black servants-Aunt Henny, Marthy, and Venus-reunited after the grandmother's rescue, but Venus gets engaged to John, Cuthbert's black servant: "Venus was to go to Massachusetts with her young mistress, and the plan was that she and John Williams should be married about Christmas" (274). As Jewel dies, the wedding is postponed, but Cuthbert's support for the union is mentioned as the first reason for his return to the Bowen mansion in the novel's closure (282). Thus, even though it is not explicitly depicted, the novel is optimistically closed with the marriage of Venus and John. Although it does not cross either class or race barriers, their union symbolically reunites the North and the South in the novel. Overall, although as far as mobility is concerned none of the black servants travel as widely as the mulatta characters in all three novels, Hagar's Daughter's subplot centered on the black lowerclass characters is a reversal of the text's main upper-class romantic plot, and it expresses hope and belief in upward progress of the black lower strata.

\section{Conclusion}

Whether hopeful or more pessimistic, all mulatta melodramas I have examined challenge the individualistic, linear narratives of male slaves by foregrounding the relatedness and familial, especially matrilineal, connections. Unlike in the mythical 
heroic quest, where the hero returns home having found the searched object (Campbell 193), in the two post-Emancipation novels-Iola Leroy and Hagar's Daughter-home has to be reconstructed and itself becomes the object of the quest. When compared to the maps visualizing the characters' movements, the novels devote much more space to the protagonists' self-determined mobility than to their initial forced travels, which are narrated in a rapid pace that characterizes Genette's notion of summary in his analysis of narrative discourse. In this way, the separations, bondage, and being taken "down the river" are represented as sudden, unpredictable, and thus even more traumatic, whereas the character's resistance is given more space and their cunning as well as bravery are highlighted. Extensive passages that depict the mobility of the female characters underline their newly regained freedom and challenge not only the limitations on travel imposed by slavery but also women's confinement in the public sphere.

The mulattas' returns to the South are opposed to Du Bois's representation of "homecoming as a regrettable instance of downward mobility" (Williams 179), but they are also different from Booker T. Washington's contemporary call to "cast your buckets where you are," commonly interpreted as an appeal to remain in the South and accept social segregation (106-108). The mulatta novels, in contrast, repeatedly expose the interracial unions in American history, and hence present social segregation as an impossible fantasy. The protagonists' return to the very plantations and mansions they come from can be read as a reclamation of their white owners and/or husband's, father's, or grandfather's property, yet the novels simultaneously privilege the black matrilineal line. The female family members reunite and build their homes on the previously white male property. Intertextually, the two later novels return to their narrative point of origin: they rewrite Brown's Clotel, the founding text of African American mulatta novel.

The circular itineraries of the novels are conspicuously at odds with the linear, beforeafter paradigm of slave narratives, but they also dramatically contrast with the domestic and stationary character of woman's fiction. Even though, as I have argued, the forced travel in the novels showcases the powerlessness of slaves rather than the agency traditionally associated with mobility, none of the discussed characters remains a passive victim, and all repeatedly resist their oppressors and escape from their prisons. Their daring flights and self-determined mobility are much more extensive than those typically found in, largely domestically-centered, Victorian hegemonic woman's fiction. As the figures in this chapter illustrate, the numerous destinations of the protagonists' itineraries range from the West Coast and California, through the entire South and Northeast of the US, across the border to Canada, all the way to and Europe. Significantly, such wide-ranging mobility is possible due to the ability of most characters to pass for white, which makes the choice of the white-looking mulatta a strategic vehicle of autonomy. It is especially visible when the phenotypically white heroines are contrasted with the visibly black and lower-class female characters in Hagar's Daughter, who travel much less widely, despite their "becoming the heroine[s] of the story" (Carby xxxix). When read in the context of hegemonic woman's culture, the novels cast shadow over domesticity by highlighting the condition of confinement related to it, yet they also powerfully demonstrate the specific condition of black chattel slavery and its difference from white domestic confinement. 

In Clotel, the desire for a complete family reunion remains on the level of counterfactuality (Dannenberg 1-17). Iola Leroy's closure-written at the dawn of the Nadir-optimistically depicts a home that reunites three generations of a mixed-race family and a happily married protagonist. Published 10 years later, Hagar's Daughter reunites the two generations of mulattas, yet denies a happy ending to its younger protagonist. Despite such a wide spectrum of closures, all the narratives are driven towards a family reunion and extended black and interracial family. In order to express such desire, they mobilize the affective force of melodramatic conventions and sentimental sympathy, whose continuing power is visible also in today's US.

Bearing in mind the risky character of historical analogies and the specific conditions of US chattel slavery, I nevertheless end this article and with a contemporary reference. Such a bridge can be further supported with Yogita Goyal's claim regarding "the ongoing appeal of sentimentalism to narrate trauma," which, she argues, is especially clearly visible in the recastings of the slave narrative in contemporary literature to "narrate[s] stories of oppression from the Global South" (3). Working on this paper in June 2018, I could not help but notice a parallel between mother-child separations and the Potomac jump scenes in the mulatta melodrama and the 2018 controversy regarding the immigrant families, representative of the Global South, separated by the US border. Both trigger identification with the familial bonds to evoke an affective response and suggest the historical, national, and public dimensions of intimate relations. Even more significantly from the perspective of this article, they both mobilize the dialectically related notions of forced and self-determined mobility (slavery/detention v. escape/migrancy), and their most powerful affective force is located in the family separations related to these complex patterns of movement. Just as the readers of Hagar's Daughter necessarily imagine the cries of the baby Hagar needs to "hush" moments before her jump into the Potomac, on June 19, 2018 guests at President Donald Trump's fundraising event listened to recordings of immigrant children crying from speakers installed by protesting activists in front of the venue ("Protesters Blast"). ${ }^{10}$ The affective force of the scene lies in what Donald Winnicott calls "a song of sadness"-the child's cry stemming from the grief that is unimaginable for adults (63). ${ }^{11}$ That musical metaphor, which he extends later in the text, representing crying as a melody that both expresses sadness and soothes its painfulness (64), echoes the poetics of melodrama, in which the Greek term melos (music) is the necessary element that intensifies the affective force of theater and literature. As Peter Brooks argues, "[t]he emotional drama needs the desemanticized language of music" and "its evocation of the "ineffable" (14) or, as Winnicott puts it, the verbally unrepresentable, "almost unbearable feelings, such as we were liable to as babies" can only be expressed in the child's "song of sadness" (63). Thus, the redemptive melodies of separation and reunion, exile and homecoming, detention and mobility continue to move and soothe the audiences, who vicariously grieve the losses of the subaltern. Although Lauren Berlant correctly points out that such mode "has been deployed mainly by the culturally privileged to humanize those very subjects who are also, and at the same time, reduced to cliche within the reigning regimes of entitlement or value" (636), she-also rightly-admits that "[t]he possibility that through the identification with alterity you will never be the same" not only constitutes a threat but also remains "the great promise of this affective aesthetic" (648). From a pragmatic standpoint, the effectiveness of melodramatic scenes and their 
"contradictory bargains with pain, domination, terror, and exile" (Berlant 663) can be tangibly observed. The day after the fundraiser accompanied by recordings of children's cries and other forms of protest against the family separation policy, Trump "bowed to public pressure and signed an executive order promising to "keep families together' in migrant detentions" ("Trump Reverses"). ${ }^{12}$ Despite the continuing racial oppression in US society, there is a difference between what Ian Haney López discusses as the present postracial racism and the past regimes of slavery or segregation challenged by the mobilities in mulatta melodrama.

\section{BIBLIOGRAPHY}

Baym, Nina. Woman's Fiction: A Guide to Novels by and about Women in America, 1820-70. U of Illinois P, 1978.

Berlant, Lauren. "Poor Eliza." American Literature, vol. 70, no. 3, 1998, pp. 635-68. JSTOR, doi: $10.2307 / 2902712$.

Blitzer, Jonathan. "A New Report on Family Separations Shows the Depths of Trump's Negligence.” The New Yorker, 6 Dec. 2019, www.newyorker.com/news/news-desk/a-new-reporton-family-separations-shows-the-depths-of-trumps-negligence.

Bost, Suzanne. Mulattas and Mestizas: Representing Mixed Identities in the Americas. U of Georgia P, 2005.

Bristow, Nancy K. Making Men Moral: Social Engineering During the Great War. NYUP, 1997.

Brooks, Peter. The Melodramatic Imagination: Balzac, Henry James, Melodrama, and the Mode of Excess: With a New Preface. 1976. Yale UP, 1995.

Brown, William Wells. Clotel: Or, The President's Daughter. 1853, edited, annotated and with an introduction by M. Giulia Fabi, Penguin, 2003.

Brown, William Wells. Clotelle; Or, The Colored Heroine; A Tale of the Southern States. Lee \& Shepard, 1867.

Campbell, Joseph. 1949. The Hero with a Thousand Faces. New World Library, 2008.

Carby, Hazel V. Introduction. The Magazine Novels of Pauline Hopkins: (Including Hagar's Daughter, Winona, and of One Blood), by Pauline E. Hopkins, edited by Hazel V. Carby, Oxford UP, 1990, pp. xxix-1.

Cott, Nancy F. The Bonds of Womanhood: “Woman's Sphere" in New England, 1780-1835. Yale UP, 1977.

Dannenberg, Hilary P. Coincidence and Counterfactuality: Plotting Time and Space in Narrative Fiction. U of Nebraska P, 2008.

Davis, Angela Y. Women, Race, \& Class. Knopf Doubleday, 2011.

Dorsey, Bruce. Reforming Men and Women: Gender in the Antebellum City. Cornell UP, 2002. 
duCille, Ann. The Coupling Convention : Sex, Text, and Tradition in Black Women's Fiction. Oxford UP, 1993.

Epstein, Barbara Leslie. The Politics of Domesticity: Women, Evangelism, and Temperance in Nineteenth-Century America. Wesleyan UP, 1981.

Fabi, M. Giulia. Passing and the Rise of the African American Novel. U of Illinois P, 2001.

Foreman, P. Gabrielle. Activist Sentiments: Reading Black Women in the Nineteenth Century. U of Illinois P, 2009.

Genette, Gérard. Narrative Discourse: An Essay in Method. Translated by Jane E. Lewin, Cornell UP, 1983.

Goyal, Yogita. Runaway Genres: The Global Afterlives of Slavery. NYU Press, 2019.

Goshgarian, G. M. To Kiss the Chastening Rod: Domestic Fiction and Sexual Ideology in the American Renaissance. Cornell University Press, 2019.

Greyser, Naomi. On Sympathetic Grounds: Race, Gender, and Affective Geographies in Nineteenth-Century North America. Oxford University Press, 2017.

Harper, Frances Ellen Watkins. Iola Leroy, or, Shadows Uplifted. 1893. Book Jungle, 2008.

Heermance, J. Noel, and William Wells Brown. William Wells Brown and Clotelle: A Portrait of the Artist in the First Negro Novel. Archon Books, 1969.

Hobson, Barbara Meil. Uneasy Virtue: The Politics of Prostitution and the American Reform Tradition. U of Chicago P, 1990.

Hopkins, Pauline Elizabeth. The Magazine Novels of Pauline Hopkins: (Including Hagar's Daughter, Winona, and Of One Blood), edited by Hazel V. Carby, Oxford UP, 1990.

Jacobs, Harriet. Incidents in the Life of a Slave Girl. 1861. Penguin, 2000.

Johnson, Lynn R. "Contesting the Myth of National Compassion: The Leap from the Long Bridge into Trans-Atlantic History in Clotel or the President's Daughter (1853)." Journal of Pan African Studies, vol. 6, no. 8, 2014, p. 11-26.

“Kush." Encyclopedia Britannica, https://www.britannica.com/place/Kush. Accessed 12 Feb. 2018.

McDowell, Deborah E. “The Changing Same”: Black Women's Literature, Criticism, and Theory. Indiana UP, 1995.

Patton, Venetria K. Women in Chains: The Legacy of Slavery in Black Women's Fiction. SUNY Press, 1999.

Pochmara, Anna. "Like Mother, Like Daughter?: The Matrilineal Opposition in African American Mulatta Melodrama," Anglica: An International Journal of English Studies, vol. 26, no. 1, 2017, pp. 165-192.

Pochmara, Anna. The Nadir and the Zenith: Temperance and Excess in the Early African American Novel. U of Georgia P, 2021.

"Protesters Blast Audio of Crying Migrant Children Outside Trump Hotel during \$100,000 a Head GOP Fundraiser." Newsweek, 20 June 2018, http://www.newsweek.com/audio-separated-migrantchildren-crying-blasted-outside-trump-hotel-during-gop-985772.

Raimon, Eve Allegra. The “Tragic Mulatta” Revisited: Race and Nationalism in NineteenthCentury Antislavery Fiction. Rutgers UP, 2004. 
Roberson, Susan L. Antebellum American Women Writers and the Road: American Mobilities. Routledge, 2010.

Rohrbach, Augusta. “To Be Continued: Double Identity, Multiplicity and Antigeneaology as Narrative Strategies in Pauline Hopkins' Magazine Fiction." Callaloo, vol. 22, no. 2, 1999, pp. 483-98. Project Muse, doi: 10.1353/cal.1999.0095.

Rosen, Ruth. The Lost Sisterhood: Prostitution in America, 1900-1918. Johns Hopkins UP, 1983.

Sánchez-Eppler, Karen. "Bodily Bonds: The Intersecting Rhetorics of Feminism and Abolition.” Representations, no. 24, 1988, pp. 28-59. JSTOR, www.jstor.org/stable/2928475.

Sánchez-Eppler, Karen. Touching Liberty: Abolition, Feminism, and the Politics of the Body. U of California P, 1997.

Silverman, Gillian. Bodies and Books: Reading and the Fantasy of Communion in NineteenthCentury America. University of Pennsylvania Press, 2012.

Smith, Valerie. Self-Discovery and Authority in Afro-American Narrative. Harvard UP, 1987.

Steadman, Jennifer Bernhardt. Traveling Economies: American Women's Travel Writing. Ohio State UP, 2007.

Stokes, Claudia. The Altar at Home: Sentimental Literature and Nineteenth-Century American Religion. University of Pennsylvania Press, 2014.

Tate, Claudia. Domestic Allegories of Political Desire: The Black Heroine's Text at the Turn of the Century. Oxford UP, 1996.

“Trump Reverses Migrant Separation Policy.” BBC News, 21 June 2018, www.bbc.com/news/ world-us-canada-44552852.

The Bible. Authorized King James Version, Oxford UP, 1998.

Tompkins, Jane. West of Everything: The Inner Life of Westerns. Oxford UP, 1992.

Washington, Booker T. Up from Slavery. 1901. Courier Corporation, 2012.

Williams, Andreá N. Dividing Lines: Class Anxiety and Postbellum Black Fiction. U of Michigan P, 2013.

Winnicott, D. W. The Child, The Family, and the Outside World. Da Capo Press, 1992.

Zackodnik, Teresa C. The Mulatta and the Politics of Race. UP of Mississippi, 2010.

\section{NOTES}

1. For a detailed examination of mulatta melodrama as a genre, see Anna Pochmara, "Like Mother, Like Daughter?: The Matrilineal Opposition in African American Mulatta Melodrama" (2017) and my forthcoming book The Nadir and the Zenith: Temperance and Excess in the Early African American Novel (2021). Although the term mulatta might seem outdated and not consistent with the jargon of today's mixed race studies, scholars writing about early African American fiction and US nineteenth-century culture continue to use it, as today's terms, such as biracial, do not fit precisely the sentimental mixed-race characters. Moreover, most of black nineteenth-century writers engaged in a dialogue with the cliché image of the passive tragic mulatta, which further explains the use of the term in critical analysis of the period. See, for example, Susan Bost's 
Mulattas and Mestizas (2005) and Teresa C. Zackodnik's The Mulatta and the Politics of Race (2010).

2. I will focus on physical mobility of characters, which is represented in the maps. Although a discussion of social mobility in the novels could be interesting and productive, it is beyond this already extensive article. For an interesting reading of distance and intimacy in sentimental literature that includes texts by black authors, see Naomi Greyser's On Sympathetic Grounds: Race, Gender, and Affective Geographies in Nineteenth-Century North America (2017).

3. For an account of the conflicting interests of suffragists and African Americans and racism within the women's movement in the postbellum era, see Davis 70-86.

4. As many critics recently have argued, the rigid paradigm of separate spheres, according to which women were "relegated exclusively to domestic rather than public life," does not accurately account for the complex ways "women participated in public life" (Steadman 9).

5. For other accounts of nineteenth-century women's popular fiction, see Cathy N. Davidson, Revolution and the Word: The Rise of the Novel in America (1986), Joanne Dobson, "The Hidden Hand: Subversion of Cultural Ideology in Three Mid-Nineteenth-Century American Women's Novels," (1986), Susan K. Harris, 19th-century American Women's Novels Interpretive Strategies (1990), ), Lora Romero, Home Fronts: Domesticity and Its Critics in the Antebellum United States (1997), and Cathy N. Davidson, editor, No More Separate Spheres!, a special issue of American Literature (1998). Among the most significant twenty-first-century studies devoted to this body of literature, there are Marianne Noble's The Masochistic Pleasures of Sentimental Literature (2000), Gillian Silverman's Bodies and Books: Reading and the Fantasy of Communion in Nineteenth-Century America (2012), Claudia Stokes's The Altar at Home: Sentimental Literature and NineteenthCentury American Religion (2014), and G. M. Goshgarian's To Kiss the Chastening Rod: Domestic Fiction and Sexual Ideology in the American Renaissance (2019).

6. In September 2017, I attended a conference on women and travel organized by the University of Silesia, called "A Suitcase of Her Own." The great majority of speakers emphasized the emancipatory character of travel for women in the nineteenth century, playing with the playful name of the conference. In my paper, I referred to this assumption, making a claim that the case of mulatta melodrama characters is more complex, as at first - in their forced travels - they are turned into chattel - they are the "suitcase."

7. In the 1864 and 1867 versions of the melodrama, Clotel is renamed as Isabella, and Mary as Clotelle, which makes her the single main character. The change in names conforms to the reader's expectations and narrative rules, according to which the novel should follow main character's actions until the end rather than kill her off in the middle, but it also takes away the cognitive shock derived from the unruliness of the 1853 narrative. When referring to the later versions, I will use both names for the sake of clarity.

8. For a discussion of Afrocentrism and cosmopolitanism in mulatta melodrama, see Pochmara, "In a Lily-tangled Bed" (2018).

9. For a discussion of white slavery and Iola Leroy, in turn, see Foreman (82-86). The metaphor of white slavery as well as the narrative of abduction seems more relevant for Hopkins's novel, published at the beginning of the twentieth century when the white slave narratives were more popular.

10. The Times's July 2018 cover, which juxtaposes Trump-a white privileged man-with a nonwhite crying child, which his policies have separated from her parents can be another relevant intertext.

11. Winnicott identifies four reasons behind children's cries: Satisfaction, Pain (including hunger), Rage, and Grief. As children have not yet learnt to defend 
themselves against painful like adults, it is difficult for us to "believe in your own infant's grief" with "direct sympathy" (63). And by sad crying an infant to some extent entertains himself. He may easily develop and experiment with the various tones of his crying while he is waiting for sleep to come to drown his sorrows. A little older, and he will be actually heard sadly singing himself to sleep" (64).

12. The family separation crisis has not been successfully resolved. Although "the President ended zero tolerance at the border," "the family separations at the border continue, albeit in different forms, and with different rationales" (Blitzer).

\section{ABSTRACTS}

In this article, I examine the patterns of black female mobility as represented in three African American mulatta novels: William Wells Brown's Clotel (1853), Frances Ellen Watkins Harper's Iola Leroy (1893), and Pauline Elizabeth Hopkins's Hagar's Daughter (1901-1902). First of all, I discuss their protagonists' movement into bondage and forced travel resulting from the withdrawal of their father's protection. Such imposed mobility is countered by the self-determined action undertaken by the black heroines not only to free themselves but also to reunite their families. As a result, their itineraries are circular rather than linear and frequently take the form of a homecoming. In contrast to the paradigm of the traditional slave narrative, which focuses on a single individual, the novels I analyze simultaneously follow two or three generations of family members. Such representations result in a chaotic aesthetics that successfully depicts the unpredictability of the fate of black families under slavery, and it foregrounds the relationality of the novels' characters.

\section{INDEX}

Keywords: melodrama, mulatta, travel writing, African American novel 